Portland State University

PDXScholar

1976

\title{
A Study of Runaway Behavior and Other Factors Impeding Treatment at Albertina Kerr Center, a Residential Treatment Center for Girls
}

\author{
June Anderson \\ Portland State University \\ Mary Coleman \\ Portland State University \\ Kristi Kennen \\ Portland State University \\ Tom Ross \\ Portland State University
}

Follow this and additional works at: https://pdxscholar.library.pdx.edu/open_access_etds

Part of the Social Work Commons

Let us know how access to this document benefits you.

\section{Recommended Citation}

Anderson, June; Coleman, Mary; Kennen, Kristi; and Ross, Tom, "A Study of Runaway Behavior and Other Factors Impeding Treatment at Albertina Kerr Center, a Residential Treatment Center for Girls" (1976). Dissertations and Theses. Paper 2372.

https://doi.org/10.15760/etd.2369

This Thesis is brought to you for free and open access. It has been accepted for inclusion in Dissertations and Theses by an authorized administrator of PDXScholar. Please contact us if we can make this document more accessible: pdxscholar@pdx.edu. 
A STUDY OF RUNAWAY BEHAAVIOR AND OTHERR FACTORS IMPEDING TREATMEHNT AT AJBERTINA KERR CENTPR, A RESIDENTIAL TREATMERT CENTTER FOR GIRLS

\author{
by \\ JUNE ANDERSON \\ MARY COLAMMAN \\ KRISTI KRTNNEN \\ and \\ TOM ROSS
}

A report submitted in partial fulfillment of the requirements for the degree of

\author{
MASTERR \\ of \\ SOCIAL WORK \\ Portland State University \\ 1976
}




\section{ABSTRACI}

This report is a descriptive analysis of data obtained from the files of girls terminated from treatment at Albertina Kerr Center between January 1st, 1975 and July 1st, 1976. The purpose of the study is to identify factors that contribute to the high runaway rate which plagues the Center, and to offer the agency suggestions for dealing with the growing problem.

Owr findings suggest that there are two groups of residents who are apt to be prematurely terminated from the program due to rroning behavior. We have called the first group character disordered children, while the second consists of children who experience extreme separation anxiety when placed in the institution. The report concludes with recomendations for dealing with the identified groups. 
TO THE OFFICE OF GRADUATE STUDIES AND RESEARCH: "

The practicum advisor approves the research report, A Study of Bunaway Behavior and Other Factors Impeding Treatment at Albertina Kerr Center, a Residential Treatment Center for Girls, by June Anderson, Mary Colemen, Kristi Kennen and Tom Ross, presented June 4, 1976.

APPROVED:

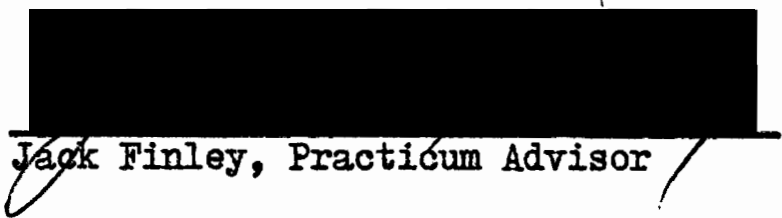


Aclonowledgements:

We wish to extend our appreciation and thanks to Mr. Rob Roy, Director of Treatment at Albertina Kerr Center for Children, for his support and guidance throughout the course of our study.

Special thanks is also extended to $\mathrm{Mr}$. Jack Finley, our practicum advisor, and to Ms. Wancy Koroloff for her special consultation.

We also would like to acknowledge Ms. Shirley Hazard for her help in typing owr material, and Gay Hancock, Director of Albertina Kerr Center for hia help in locating relevant reference material. Finally, we wish to thank our typist, Ms. Winnie Finjord. 
TABLE OF CONTERTS

PAGE

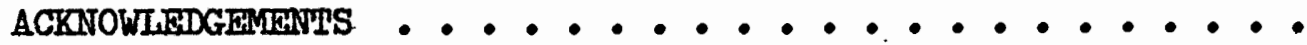

iii

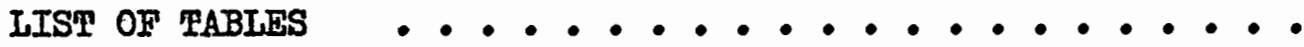

$\mathbf{v}$

GHAPTER

I IITIRODUCIION . . . . . . . . . . . . . 1

The Problem •. •. . . . . . . . . . 1

Parpose of the Study ............. 2

Agency Philosophy and Setting ........ 3

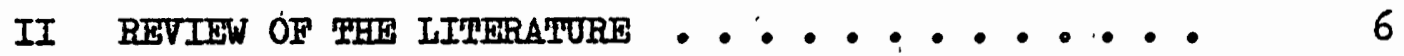

Concepts of Treatment ... . . . . . . 6

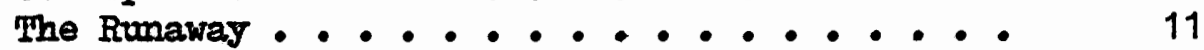

III MEIHODOLOGY

Questions to be Studied.......... 23

Definitions ................. 25

Methods of Data Collection and Data Analysis. - 27

IV PRESERITATION OF DATA . . . . . . . . . . 30

V CONCLUSIONS .................. 42

Implications . . . . . . . . . . 42

Recommendations ............. 49

Areas for Further Research .......... 51

FOOTIOTES

BIBLIOGRAPHY •. . . . . . . . . . . . . . 56

APPEHDICES 
IIST OF PABIES

TABLE

PAGE

I Geographical Iocation . . . . . . . . . . 31

II Fconomic Status of Parents . . . . . . . . . 32

III Child's Position in Sibline ............ 32

IV Out of Home Placements Prior to Placement . . . . . 33

$\checkmark$ Recorded Runaways Prior to Placement . . . . . . 33

VI Child's Alcohol or Drug Jse Prior to Placement • • • 34

VII Parents' Use of Alcohol . . . . . . . . . . 34

VIII Children's Chronic Health Problems . . . . . . • 35

IX Natural Parents' Marital Status . . . . . . . . 36

X Length of Time Separated - Natural Parents . . . . 36

XI Child's Piace of Residence Before Placement . . . . . 37

XII Statutory Offenses Prior to Admission . . . . . . 37

XIII Number of Runaways Daring the Pirst Three Months - . 38

XIV Jiving Group Placement. . . . . . . . . . . 39

XV Parents Involved in Treatment . . . . . . . . 39

XVI Pre-Placement Visit .............. 40

XVII Length of time in Residence . . . . . . . . . 40

XVIII Comparison of Delinquent Behaviors ...$\cdot$. Appendix B 
CHAPIER I

TNTRODUCFION

\section{The Problem}

This study was undertaken at the request of Albertina Kerr Center, a residential program for teen-age girls, where staff have been troubled by the accelerating problem of munaways from the facility. The hazards facing the girl on the run, the intensification of her problems as a result of running, the break in the continuity of hex treatment program and other logistic complications, constitute the basis for serious concerm. This concern has intensified due to the increased number of girls being prematurely terminated from the program because of runaway behaviox.

Premature termination of treatment has three separate facets. First there are the pre-existing factors within the girl and her enviranment, from which she has developed the pattern of coping with problems by flight. These factors, though extermal to the treatment facility, continue to influence her after placement. Probably the most potent of such influences is the family.

Second, there are factors internal to the agency which are significant, such as staff tumover, lack of adequate orientation, and limitations of the facility.

Finally, there are the philosophical differences between the agency and the community which constitute the third facet of the problem. 
Albertina Kerr Center recognizes that running away may be an experience which can be integrated into the treatment process if a girl returns and is confronted with the consequences of her behavior. The community, however, may see her mans as a failure of the treatment program. In many instances the girl who has ran is not returned to the Albertina Kerr Center after she has been located, but is placed elsewhere by her caseworker, her family or the court. The girl who is aware of this possibility may perceive running as a means of aroiding behavior change, and specifically as a means of getting out of the Albertina Kerr center.

The present study is an outgrowth of Albertina Kerr Center's search for ways of dealing with their runaway problem.

\section{Purpose of the Study}

Fssentially this study is desigeed to explore some of the demographic, social and institutional factors thought to be related to premature termination of treatment. Our purpose is to determine whether, on the basis of the above factors, it is possible to distinguish, at referral or early in the program, between girls who will achieve their treatment goals and those whose treatment will be terminated without behavior change. We have placed special emphasis on runaway behavior because running away has been identified by the Albertina Kerr Center staff as the primary reason for premature termination of treatment. Our objective is to contribute descriptive information to Albertina Kerr Center which may be useful in dealing with the problem the agency has identified, by pointing to possible modifications in policies, programs, and procedures, and by identifying areas needing more definitive research. 
Since the problen of premature termination due to runaway behavior is common to residential treatment centers in this area, we hope the results of the study will be informative to other agencies and institutions providing a similar service.

\section{Agenoy Philosophy and Setting}

To understand the unique problems besetting Albertina Rerr Center for Children it is necessary to examine 1) the philosophy of treatment and 2) the physical setting, because both are influencing the life experience of the child in residence. The agency staff has been struggling to determine the reasons for their high rate of runaway. Both the treatment philosophy and the living facilities are presently under examination to determine areas of potential change which might provide more effective care and treatment of the adolescent in the residential program.

Basically the Albertina Kerr Center treatment program has been developed on the principles of a therapeutic commity. This therapeutic community model offers a total approach to treatment of disturbed adolescents, in the belief that all interpersonal interaction offers the opportunity for a therapeutic' experience. The Center's program involves two primaxy assumptions: 1) The child's anti-social behavior is seen as an interpersonal and social phenomenon which reveals itself in the girl's troubled relationships with people; and 2) the Center's social milieu is regarded as a primary means of treatment because it provides the girl with an environment to test out new and successful behaviors in a safe atmosphere. An important aspect of milieu therapy is the constant feedback the child receives from her peers and 
significant adults, providing her with support and reinforcement to continue these new, more positive behaviors.

A team treatment approach is in effect at Albertina Kerr Center. There are four treatment teams, each comprised of a social worker, a lead child care worker and several child care workers. Each team is assigned to a particular living group which cares for seven to fourteen girls. Each team operates a program reflecting the needs of the children in their care, emphasizing particular talents of team members. The use of the small group concept allows for stability, consistency and close relationships between staff and girls.

Various modes of treatment axe available to the girls, including peer group therapy, individual therapy, single family or multiple family. therapy, and mother-daughter group therapy. The living group also conducts group meetings weekly to deal with the problems related to group living. Further, the girls are given feedback regarding their behavior in weekly progress reports initiated by the child care staff. These reports give the girls additional information about their progress within the group.

Presently Albertina Kerr Center has an open-door policy: During the day there axe no locked doors and the girls are allowed to come and go as they please, providing they secure permission of staff. Rationale for the policy is that the girls mast leam inner control, learning which is best acquired when the setting does not impose extermal physical restraints.

The facility consists of three buildings. The main building, known as Kathryn Carlson Home, includes three living groups or "halls" called Iynn, Jean and Hobbit. The home building serves approximately 
thirty girls. The two remaining buildings are James Lakin Cottage, which accommodates a maximum of thirteen girls, and the Max Tuckex cottage, which houses eight boys. Both the Kathryn Carlson Home and the James Lakin Cottage serve as residential treatment facilities for emotionally disturbed and delinquent girls, ages 12 through 17 years. The Max Tracker cottage, which serves as a treatment facility for younger boys, was not included in our study because of its different population and treatment focus. The program, featuring a behavior modification approach, provides locked doors and close supervision. Wynne Watts High School, located on the Albertina Kerr Center campus and operated by the Reynolds School District, serves the girls' educational needs. It is considered an important component of the total treatment experience, and girls' classes are carefully planned to meet their individual abilities and interests. Although a majority of the girls attend Wynne Watts, a few attend other public high schools within the community, provided they meet the educational and behavioral requirements of the particular school. Often public school attendance is the last step leading to a return to the community. 
CHAPTER II

REVIEW OF THE LITERATURE

\section{Concepts of Treatment}

Schools and institutions for the youthful offender have a fairly long history in America. The first such establishment, the New York House of Refuge, was opened on $1 / 1 / 25$. Clyde Vedder (1963) ${ }^{1}$ states: "The founders of this House envisaged the institution as a 'prison, manufactory and school.'" Other such institutions, called reform schools, were founded in the $1800 \mathrm{\prime}$, including the first Industrial School for girls, located in Iancaster, Massachusetts. Vedder notes that the term "Industrial School" was used in an effort to remove the stigma attached to the earlier label of "Reform School," but this name also developed undesirable connotations and eventually it became common practice to name correctional centers for persons or locations in an effort to aroid the stigmatizing label. However, as Vedder points out, name changing was not highly effective in changing the "Reform School" image, particularly since many such institutions were slow to revise their practices.

Traditionally the focus of American institutions for juvenile offenders has been punishment rather than socialization, despite the fact that the emphasis on punitiveness "seemed to produce only more hostile and agressive responses from most boys and girls." ${ }^{2}$ 
Bratality and indifference were widespread in juvenile institutions in the mid-1900's, particularly in boys' schools but existing in institutions for girls as well. For example Vedder mentions the Home of the Good Shepherd in a western state:

-in which are confined all delinquent girls, since the state has no other facilities for them... Frustrating pressures (exist)...the girls are forbidden to talk or communicate in any way while in the dormitory... All the discipline is tied to a point system, stars given for so many points. Unusually good behavior earns an extra star, insolence can lose a star, and running away can lose all stars. Two stars allow a two hour visit with the girl's family. 3

In general, Vedder questions the validity of institutionalization as an effective means of reconditioning offenders, and sees as a "hopeful trend" those facilities which "simulating home conditions, ...provide a background generally more suitable to rehabilitation." 4

Slater, Cowie and Cowie $(1968)^{5}$ do not see institutional care of the delinquent girl as necessarily counter-therapeutic. These authors studied 318 girls, ages 14-16, who were committed to the Magdelan Hospital Classifying School, a correctional school for girls in Hingland, during the year 1958. Three quarters of the girls in the study were ad-

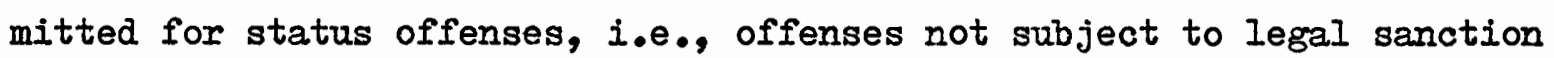
after age 17. The remaining quarter were primarily charged with theft. After investigating personal characteristics and family relationships the authors conclude:

To us it seems more than doubtful whether children should be allowed to go on living in a hostile environment, just because it is the parental home, once their neurotic or delinquent reaction has been shown. It is indeed a widespread view that children should not be removed from their natural home even when it is a bad one... This opinion is based on no good evidence that we know. There is no evidence that institutional life as such mast be detrimental..(though) Admittedly, in the 
past, institutions have lacked much that we now recognize as vital for the child's needs. 6

New trends in managing delinquent youth appear to be based on a growing awareness that the punitive approach of the past is ineffective, combined with an increased understanding of the children's needs and the belief that some families are too inadequate or pathological to socialize their children.

Since current residential programs tend to focus on socializing or treating the delinquent youngster rather than punishing him, it seems appropriate to consider, briefly, some of the factors which are believed to be involved in the development of the delinquent. Ruth Caran (1962) 7 reviews the subject comprehensively, documenting her position:

One by one the attempts to find a unitary explanation of all delinquency have failed..each child works out his adjustment to himself as a unique being through the gaiding complex of sociomcultural relationships which he experiences. 8

Some important factors Ms. Cavan recognized are group associations, cultural expectations, and unfarorable family conditions. Like the writers mentioned earlier, she places particular emphasis on the family, citing studies which indicate:

Delinquency-prone families as a group have a greater proportion of rejecting or harsh parents, parents who impress their children as indifferent to their welfare, parents who are erratic or lax in discipline, or who offer little for the (children) to admire or emulate. Delinquency-prone families are more likely than other families to be broken (for some delinquents there is no family at all), with the female-based family a common type in some groups. The delinquency-prone family frequently is financially dependent on outside assistance or public relief... There is evidence that an accumulation of unfavorable factors increases the likel thood that the (child) will become delinquent. 9

Ms. Cavan mentions the relative scarcity of studies of delinquent girls. Based on the fragmentary material available she concludes: 
Girl delinquents resemble boy delinquents in age distribution, concentration in lower socioeconomic areas, and background of disorganized family life. Delinquent boys seem to be struggling to reach masculine values of success and status through various competitive devices such as outwitting police, showing courage superior to that of other delinquent boys, and finding a way to gain money without hard work. The delinquent girl is concermed with evading unpleasant interpersonal relationships at home and establishing successful relationships with boys, often defined in terms of sexual attraction. 10

The delinquent girl, from this point of view, is primarily coping with a problem of interpersonal relations.

The therapeutic community model for treatment of delinquency is founded on this premise. Further, it is "based on the assumption that the social milieu itself can be the instrument of treatment.. (that is) that people change, learn and mature as a result of their interpersonal and social relationships and experiences." (Kraft 1966) ${ }^{11}$ In this treatment model, the traditional distinctions between delinquent and emotionally disturbed children may be seen as irrelevant. Regardless of the means by which a child chooses to express his disturbance, he is essentially responding to an environment with which he cannot cope.

Kraft identifies 5 characteristics of a therapeutic community, including: 1) Emphasis on social and group interaction, 2) Focus on communication, 3) Use of all aspects of daily life as living-leaming experiences, 4) Shared responsibility of staff and residents, and 5) Role expansion, in which traditional sharp delineations between residents, staff and related professionals are blurred. The aim of the therar peutic community is to create a milieu in which individuals may "gain an awareness of their feelings, thoughts, impolses and behavior...try new skills in a relatively safe environment....achieve a realistic appraisal of their social and interpersonal environments...and increase 
their self esteem. ${ }^{12}$ Group process and a close relationship with the outside community are important features of such a program.

Fritz Redl (1972) ${ }^{13}$ whose thinking was basic in applying the therapeutic community concept to residential treatment for children, identifies 12 aspects of the milieu which must be considered in creating a treatment program for youngsters. Redl points out that the complexity of the milieu is an important consideration, in that the multiple interactions of youngsters, staff, and outside community are difficult either to predict or evaluate in terms of their impact on an individual child. Redl underlines the need for further investigation into the milieu, how it influences individuals and how it is created and molded by them.

In 1950 an experimental treatment center for delinquents was established, utilizing some of the principles of the therapeutic community. Highfields, (McCorkle 1958) ${ }^{14}$ a small facility associated with the New Jersey System of Corrections, houses 20 boys with serious delinquency records. Basic values are security, flexibility and nonpanitive, non-aggressive attitudes on the part of the staff. The key part of the program is the group session, meeting five evenings a week. The boys bring out their problems in free discussion, gaining an understanding of the motivations for their misbehavior as well as being welded into a primary group. There are only two stanaing rules: 1) No boy may leave the grounds without being accompanied by a staff member, and 2) No boy may speak to the women who are patients at the hospital where the boys work part-time. All other rules are made by boys and staff together, and the group handles infractions. The boys have considerable freedom within the grounds, and may be given additional freedom outside the facility, with consent of the staff. A relationship is maintained with 
the outside community through frequent contact, both on outings and in daily work experience in a nearby neuropsychiatric hospital.

Evaluative research reported by Ruth Cavan indicates that

Highfields is somewhat more successful than the New Jersey State Reformatory for Males, in terms of recidivism. While results are not conclusive, Ms. Cavan states that "Highfields...is regarded as pointing the way toward new methods of rehabilitation for youthful offenders." 15

\section{The Runaway}

"You can't treat 'em if you haven't got 'em." 16

While Albertina Kerm Center, like Highfields, is based on a new and promising concept of treatment, it is plagued with an increasing runaway problem which undermines the treatment process in a large number of cases. This section of the review will therefore focus on literature relating to the munaway, with emphasis on the relationship between delinquency and running, causes of running, and studies concerned with youngsters who run from institutions.

Throughout the Iiterature attention is given to the fact that the phenomenon of runaway youth is common in our modern society. Writers differ, however, as to the import of the phenomenon. An important issue is whether or not running is an indication of delinquency. James Hildebrand, $(1963)^{17}$ in "Why Runaways Leave Home", regards muning as a danger signal, the muner as a "pre-delinquent." As a police officer, he is aware that $70 \%$ of all delinquents have a history of running. His study suggests that poor home environment, including parental apathy, school problems and sexual concerns are the major factors which cause a youngster to mun. 
A second study which suggests that manning behavior is predictive of delinquency was made by Ivan Nye and James Short (1957)! $0^{18}$ They Iisted 12 antisocial behaviors and asked a normal high school population and the residents of a boys' training school to rate the behaviors they used most frequently. They found that less than $10 \%$ of the high school population listed muning as a preferred behavior, while more than $61 \%$ of the residents of the boys' training schools were runners. The study clearly implies a relationship between social deviancy and ranning behavior.

Another point of view is taken by Shellow et al, $(1967)^{19}$ in a study designed to determine whether or not running away is necessarily pathological. Choosing a sample of 776 young people listed as missing during a one year period, they concluded that runaways fell into two groups. The first group, relatively small in number, consisted of young people whose running was related to individual or family pathology. The second group, the majority, consisted of youngsters with no serious disturbance. These were normal young people who ran only once in response to an immediate circumstance.

Iillian Ambrosino $(1971)^{20}$ mentions that technically runaways are law breakers. A runaway can be arrested if the parents report the child's unauthorized absence to the police. Thus a child can be categorized as a delinquent for the act of running away. In a recent study of the runaway problem, Greer et al. $(1972)^{21}$ conclude "running away is not a valid predictor of serious delinquency; although since running away is presently labelled delinquent behavior, runaways are likely to have previous and future delinquency." The authors imply that the delinquency label may operate as a self-fulfilling prophecy. 
Douglas Thom $(1933)^{22}$ represents the extreme position that there is no pathology in running away. He wrote in the $30 \mathrm{~s}$, "Every year, innumerable children 'run away' for no outstanding reason. They are pushed on by the spirit of wanderlust that urges the more venturesome to seek new scenes, new faces, new experiences, and real adventure."23 Thom's view is not representative of most authors, however. The majority of studies suggest some psychological or environmental determinants, or a combination of both, which motivate a youngster to run.

In the population involved in our study, there is considerable evidence of deviancy or pathology, though views differ as to causal factors. Much of the literature concerning munaways deals with the issue of causation. Most frequently the runaway is seen as a symptom of family pathology; for example A. Robey and R. A. Rosenwald $(1964)^{24}$ studied 42 runaway girls and their families in a clinical setting. In the families, which were all intact, they found a general patterm of immature parents who had poor impulse control and a disturbed marital relationship. The girl was subtly pushed by her mother to grow up too soon, take over household responsibilities, and develop a close relationship with her father. When the girl developed sexually the father responded by becoming over-restrictive, and the girl ran from her father's restrictions, her own incestuous wishes, and the fear of causing family dissolution. D. Wylie et al. (1958) 25 have a similar view of the runaway as a symptom of disturbed family relations. The authors present a case example in which treatment of the mother of a runaway girl successfully re-integrated the girl into the home.

Randall Foster $(1963)^{26}$ studied 175 jurenile delinquent boys and girls, dividing them into runaway and non-runaway groups. He obtained 
information in three areas: 1) Demographic, 2) Information regarding the parent-child relationship, 3) Information regarding the runaway activity of the experimental group. He found a greater incidence of parent-child separations among the runaways, usually from the father and occurring before the child was five years of age. There was more often a step-parent in the home in the runaway group than in the homes of the non-runaway subjects. Foster also found that the incidence of physical aggression and open sexual activity in the home was three times as frequent in the runaway's homes. The author concludes from his study' that..."the loss of a parent or the presence of a substitute parent is not in itself sufficient to determine this symptom, (running) nor is an intact family a guarantee that a child will not run away." 27

Linda Blood and D'Angello Rocco $(1974)^{28}$ studied runaways with respect to value conflicts existing between them and their parents. They studied both male and female runaways, using a control group of non-runaways. They constructed a thirty nine item instrument which differentiated runaways from other adolescents on 15 items, 8 of which were considered minor, 7 major. They hypothesized that minor issues were being used as proving grounds to test parental love. Their study revealed that key issues between munaway youth and their parents were parental failure to express love, parental non acceptance of the child, and parental lack of respect for the child's ideas and judgements. Rocco and Blood conclude that "it appears parents who recognize the adolescent's right to self expression and dissent are demonstrating a form of acceptance. ${ }^{29}$ They concluded that the conflict between parents and youth might be reduced to lack of communication. Runaway youth's parents don't listen, and may suppress expression on the part of the 
child by aggression and disengagement.

Morris Riemer (1940.) $)^{30}$ also concluded that the basic factor creating runaway problems is the lack of parental love for the child, brought about by inadequate parenting. The child, whose early needs are unmet, builds a strong system of defenses in which he denies feelings of helplessness. These defenses are expressed in negative attitudes which make it even more difficult for him to meet his needs. Unable to cope with an unyielding environment, he runs in an urge to find a new parent who will support and love him. At the same time, his run is an expression of his hostility toward the parents who failed to meet his needs.

Balzar (1939) ${ }^{31}$ studied 300 cases in a psychiatric clinic in New York. He found that among the 300 patients, 89 had the behavior problem of running away. He noted the causes of running to be:

1) Family problems or emotional problems in the home -26 cases. 2) Children from broken homes - 19 cases. 3) Young wives and mothers - 13 cases. 4) Undetermined causes - 10 cases. (These, he speculated, were sociological causes related to the depression.) 5) Economic insecurity - 9 cases. 6) Specific physical and/or mental problems, e.g., deformities, being homosexual, or being mentally defective -8 cases. 7) Spirit of adventure -4 cases. It is interesting to note that in 1939, of the 300 cases seen in this clinic for disturbed youth, only 89 were found to have a runaway problem. The incidence of running has apparently increased dramatically since that time.

This point is emphasized in the study done by Greer et al. ${ }^{32}$ in 1972. Their study, which attempted to distingruish between chronic runaways, non-chronic runaways, and non-munaways, has statistical 
support for the escalation of the problem in the last decade. Their study was conducted in Oregon, and showed that in 1971 about $24 \%$ of the delinquency referrals to Multnomah Juvenile Court were because of runaway behavior. This represents the largest category of referrals to the court, and signifies a tremendous social problem. The study states, "In the last 5 years, running away has increased about $7 \%$ in proportion to the total delinquency referrals to the court. Thus the evidence seems clear that this pattern of behavior is becoming increasingly frequent." 33

The Greer study also Identified 15 variables that occurred statistically more often in runaways than in non-runaways, or that showed a greater tendency to be associated with manaway behavior. These include: 1) Sex. Runaways were likely to be female. 2) Parents' marital status. Runaways were likely to have natural parents not married to each other. 3) Iiving arrangements. Runaways were apt to mun more frequently from institutional custody than from a natural family or a foster home setting. 4) Feelings toward parents. Runaways had more negative attitudes toward parents. 5) Siblings. Runaways were more likely to have "unnatural" siblings (that is, siblings related by another marriage of the natural parent). 6) Ordinal position. Runaways tended to be the oldest child in the family. 7) Trouble in school. Runaways experienced more trouble in school than non-runaways. This study concludes with the hope that the future will bring a reassessment of the concept of delinquency, removing the stigma of delinquency from behavior which is not criminally destructive. "Even when dealing with seriously deviant youth, the juvenile justice labelling process may have effects which are in the long range detrimental to the healthy adjugtment of adolescents." 34 
In sumary, literature relating to runaways suggests that some juvenile runaways are delinquent, while others may run away for quite a variety of reasons. In instances where intemal pathology and/or disruptive relationships with parents are involved, those children whose problems escalate to the point of their being labelled delinquent are apt to be the popalation in the residential treatment center.

There are some stadies in the literature directly related to the problems of runaways from institutions. Greenburg, Blank and Argrett $(1968)^{35}$ studied runaway problems in a Iunaway treatment center. The authors suggest that running away is a highly complex act. They conclude that, as in other acting out behavior encountered on adolescent wards, staff dysfunction can be the primary causal factor. They also mention that running away can cause considerable tension in a staff which was previously functioning very well in a treatment milieu. Greenburg et al. recognized different kinds of ruming away and attempted to type the runs and the runaways as follows: 1) Elopement arising from the staffclient relationship. 2) Elopement as a function of parental resistance. 3) The charismatic eloper. This is the one who must escape from being locked up. 4) Elopement as a predischarge protest. 5) The scapegoated eloper, the one who is not accepted by his peers. 6) The near-group eloper. This is a subculture consisting of scapegoated elopers. 7) The starcrossed lovers, who feel that they are destined to mun away. 8) Elopement and treatment shock, i.e., those who are overwhelmed by the fdea that someone cares. 9) Flopement caused by staff dysfunction. Three duate students at the School of Social Work at the oniversity of Utah (Hale, Ninnes and Huling, 1966) 36 studied the runaway problem at the Otah State Industrial School. The first study, by Hale, 37 
compared non-runners, ranners (students who ran once), and habitual munners, in relation to: 1) Characteristics of individual students, 2) Factors relating to commitment and runs, and 3) Relationship experiences. This study found that the culture represented by ethnic groupings did have some bearing on the tendency to run from the institution, and that traumatic life experiences were also significantly related to the runaway behavior of the students. In particular, early divorce of parents appeared to be a factor in the habitual runners' lack of adjustment to the school community. Hale further found that over one half of the students who ran from the institution ran during the first two months of confinement. He remarked that "the facts indicate that lack of adjustment to the instiptution is seen in the student soon after commitment and that the longer a student stays without running the more he is likely to refrain from manning." 38

The second part of this study by Ninnes 39 focused on demographic data pertaining to the student and his family. In his sample, nonrunners were the eldest, and habitual runners were the youngest of the population. He confirmed Hale's findings that runners and habitual runners ran during the first two months, with a marked decrease during the second two month period. Further it was found that the occupation of the runners' parents did not differ greatly from the non-runners' parents, and the source of the family income did not differ greatly between groups. Family factors in general did not appear to differ greatly between the two groups.

Part three of the Utah study was done by Huling 40 who compared the groups to see if the nature of the offense which resulted in commitment could be used as an index to predict runaway behavior. 
He found no significant difference between runaways and non-runaways in terms of the offense, nor did he find differences in other questions considered, such as whether or not students sniffed glue, smoked or drank.

In 1975 a study was done by Loris Colbath et al. ${ }^{41}$ at the Portland State University School of Social Work. This group studied manaways from six residential treatment agencies, one of which was the Albertina Kerr Center. The purposes of the study were: 1) To examine a sample of both runaways and non-runaways at these treatment facilities. 2) To determine the type and amount of pre-placement visitation and counselling done within the agencies. 3) To determine the effect pre-placement visitation and counselling had upon the sample studied, with respect to decreasing or controlling the number of runs from the agencies involved. 4) To determine whether or not there were significant differences between runaway and non-runaway populations. In that study they found no statistically significant differences between runners and non-munners with respect to whether or not pre-placement counselling and visitation occurred. In examining other factors differentiating runners and non-runners, they found that school attendance, the marital status of parents, whether or not the child had been adopted, the number of placements prior to coming to the agency, and the average number of weeks spent in placements other than home, were not significantly different between groups. The only variable that was significant was the place of residence. Subjects were more likely to mn if their residence was outside the Portland Metropolitan area. The authors note that the location of the placement appears to be important in relationship to the young peoples' homes and is a matter worthy of consideration when the 
child is being placed in a treatment center.

Stanley Levine $(1962)^{42}$ studied 74 boys who ran from the Illinois State Training School during a 16 month period. Like Colbath et al., Levine found that students whose homes were some distance from the institution were more apt to run than those whose homes were nearby. He also found that a large percentage of the runaways occurred before the student had been in the institution 30 days. He hypothesized that the high sunning occurrence was due to separation anxiety. The nature of the offense was also found to be significant. The boys who were referred because of escapist behavior, e.g. alcohol and drug usage, were 4 times as likely to run as those referred for other offenses. Levine used the results of his study to recommend revisions in intake procedures at the Illinois State Training School. The first recomendation was that the child should be brought into immediate contact with a supportive adult who could be counted on to maintain contact with the child throughout his stay at the institution. The second recommendation was that the child be given a tour of the grounds immediately upon his arrival, amd familiarized with his surroundings as completely as possible. The third recommendation was that the child should be put in a small group immediately, to allow him to ventilate his anxiety and express the other feelings he experienced as a result of his placement.

John Cambareri et al. $(1960)^{43}$ conducted an experiment at the Jtah State Industrial School, using a new treatment approach to the specific problem of the mun-away. The Utah State Industrial School has an open campus, making it easy for students to run. Sixteen boys, who accounted for $60 \%$ of the runs at the time of the study, were selected for the experiment. The authors developed three groups for these boys, 
equally divided, and instituted social programs as well as therapeutic discussions held on a regular basis. The three groups differed in leadership and method, but all were found to be effective. The results supported the view that rranning was due to separation anxiety, which was effectively dealt with by helping the boys develop positive ties at the Center, consequently feeling less urge to mun.

Since Albertina Kerr Center population includes both emotionally disturbed girls and delinquent girls, it seems relevant to include a study dealing with munaways from a treatment center for the emotionally disturbed. Edwin Z. Levy $(1972)^{44}$ studied female patients who ran away from an adolescent residential treatment unit at the Menninger Clinic Children's Hospital. He found that 5 categories emerged describing the positions of munaway girls: 1) Angry defiance. Running away was a demonstrative act, which gave the girls an opportunity to communicate and bargain. 2) Psychotic disorientation. 3) Escape. To get away and stay away. 4) To go on one's own. 5) Fusion with paxents. Girls placed in the institution desired to communicate with, or be with, their parents. Levy also found that adopted patients are a high runaway risk. of 11 adopted girls, $8 \mathrm{ran}$, as compared to 31 non-adopted girls, 8 of whom ran. In summarizing his findings, Ievy described factors contributing to running away as: 1) Group dynamics, 2) The striving for independence, 3) Feelings of abandonment caused by being adopted, family moves, parental travel, or death of a parent.

The final study in this section is not specifically concerned with Iunaways, but does deal with the population of a training school and does consider some of the factors which are also dealt with in our research. K. M. Koller $(1971)^{45}$ studied parental deprivation, family background, 
and female delinquency in a training school in England. One hundred twenty one students were studied, ages 16 and 17. These girls.were admitted for reasons similar to those of the Albertina Kerr Center popalation. Koller defined parental loss or deprivation as "Ioss or continuous absence of one or both natural parents for at least 12 months before the 15 th birthday. "46 He found that $61.5 \%$ of the residents had. experienced prolonged parental loss, much more than the control group of non-institutionalized youth. In most instances the missing parent was the father, or both parents. Koller also studied the birth order of the girls, excluding the children who left the family or who died soon after birth. He found that the middle child occurred at more than the expected frequency, in contrast to other studies, which suggest that the oldest or the youngest child tend to be more delinquent. 
CHAPTER III

MEIHODOLOGY

Questions to be studied

There are three general questions we are examining in this study:

I. Is there a difference between groups based on demographic factors, such as ase, race, Iocation of family residence, family's economic statas, and position in sibline?

II. Does the social history of the Unplanned Release group differ from that of the Planned Release group?

A. Is there a difference in number of out-of-home placements prior to admission?

B. Is there a difference in number of recorded runaways prior to admission?

C. Is there a difference in the percentage of children using drugs or alcohol prior to admission?

D. Is there a difference in the number of parents reported to use alcohol by the referming social worker?

B. Is there a difference in the number of children having chronic health problems prior to admission?

F. Is there a difference in the number of parents having chronic health problems at the time of a child's admission? 
G. Is there a difference between groups based on natural parent's marital status?

H. Where the family is disrupted by divorce or separation, is there a difference in the length of time since the separation of the natural parents?

I. Do the two groups differ in their living arrangements before admission to Albertina Berr Center?

J. Do the two groups differ with respect to kind and sexiousness of law violations prior to admission?

K. Is there a difference in school achievement as measured by appropriate grade placement?

I. Does one group include more adopted children than the other?

III. Are there differences in post-admission treatment and behavior?

A. Are there differences in the number of runaways during the first three months after admission?

B. Is there a higher incidence of children who end up as Unplanned Releases in some living groups?

C. Is there a difference between groups in the frequency with which parents are involved in treatment?

D. Are children who have had pre-placement visits more likely to fall in the Planned Release group?

F. Is there a difference in length of residence between the two groups? 


\section{Definitions}

Alcohol Use. - Any use of alcohol significant enough to be mentioned in a girl's referral lettex or medical report. No distinction is made between occasional and frequent drinkers.

Character Disorder. - A personality disorder, characterized

by: 1) An individual's inability to form lasting, intimate relationships. 2) Lack of internal impulse control. 3) An inability to learn from previous experience. 4) Iack of identification with societal norms. 5) Lack of clear personal identity.

Chronic Health Problem. - Any persistent medical or psychological problem which impairs functioning to some degree. Such problems may range in severity from chronic uppen-respiratory infections to totally incapacitating ailments such as severe emphysema.

Custodial Parent. - The natural parent who had physical or legal custody of a child in instances of parental divorce or separation.

Druge Use. - Any use of drugs mentioned in the referral letter or medical report. No distinction is made between marijuana and other habit forming or addictive drags, nor are habitual users distinguished from occasional users.

Institution. - The term is used here to designate any official residential facility larger than a group foster home, such as emergency homes, juvenile detention facilities, child-care centers, etc.

Iiving Group Placement. - The particular cottage or living group to which a resident at Albertina Kerr Center is assigned. Metropolitan Area. - This area includes Mralnomah, Washington and Clackamas Counties. 
Middle Class: - For purposes of this study we used the term middle class to distinguish all families who were self supporting rather than dependent on Public Welfare. We did not have sufficient information to make a finer distinction.

Open Campus. - A residential treatment setting which does not utilize security measures such as locked doors.

Out-of-Home Placement. - Any Iiving arrangement where the person designated as responsible for a girl's care and custody is not a natural parent. The term includes relatives' homes, foster homes, institutions, placoment with friends, etc.

Referral Letter. - A document provided by the individual or agency referring a firl to Albertina Kerr Center. The letter includes comprehensive information about the girl and her family, according to an outIine provided by Albertina Kerr Center. This information is used to decide whether or not an applicant is accepted for residential treatment. Run-away. - An mauthorized departure from Albertina Kerr Center, when a girl is absent long enough to be reported missing on an official report form. Length of absence ranges from several hours to a number of weeks.

Status Offense. - Any offense which is illegal only if comnitted by a jurenile, e.g. runaway, curfew violation.

Statutory Offense. - Any offense which would be illegal regardless of the age of the offender, e.8. theft, assanlt. Preatment. - Any encounter between Albextina Kerr Center staff and a girl or her parents in which the explicit purpose is to modify behavior, attitudes or otherwise promote constructive change. Contacts with parents for the purpose of exchanging information are excluded. 
Unplanned Release. - A girl is categorized as an Unplanned Release when her residence is terminated prematurely; i.e., before she has made satisfactory progress toward her treatment goals. Usually such releases occur following a muaway : from which a girl does not return because: 1) She cannot be located. 2) Her parents allow her to return home. 3) The agency (usually Children Services Division) having responsibility for the girl ahooses to place her elsewhere.

Upper Class. - This term refers to families whose income, estimated from parents' occupation and other available information, appeared to be substantially greater than the average "midale class" family described in this study. In more ustal terms these families would probably be categorized "upper midalle class."

Methods of Data Collection and Data Analysis

Our initial plan was to compare success and, non-success groups from January 1, 1974, through July 1, 1975. The first step in setting up the research design was to define our terms, decide what to look for and how to obtain data to answer our questions.

The meesurement of success or non-success in this program posed a big problem, since such measurement would need to be done on an individual basis. Success is difficult to define and nearly impossible to measure since factors such as "self concept" and "the nature of interpersonal relationships" are intangible. Our population was laxge and most were released and unavaliable, therefore a precise meesure of behavioral and attitudinal change was not possible within the limits of this study. If a precise before and after study was not feasible, we faced the question of how success was to be defined and measured. 
We chose to respond to this question by developing criteria based on an agreement between agency personnel and the research team. Since Albertina Kerr Center wanted data which would distinguish success or non-guccess groups as early as intake, we agreed, after consulting the appropriate agency sțaff, to sulstitute the term "planned release" for success and "unplanned release" fof non-success.

We collected data to answer our questions by first examining individual case records to see what information was available. Second, we interviewed the director of treatment and three social workers who were. each responsible for a distinct treatment team. Drawing upon what agency personnel deemed as important questions, we constructed a face sheet to be used in abstracting data from individual case records. Within individual case files we found the referral letter and medical. history taken by the registered nurse at Albertina Kem Center to be the best source of descriptive data.

In setting up the design, we were forced to exclude sone interesting variables due to a lack of objective information. For example, we were interested in the immediate influence of the peer group during the first week after admission, but this variable would be interpersonal, highly subjective, and depend upon the recall of staff members. The number of variables examined was also limited by the need for consistent data among 85 admissions, the omission of required material from the referral letter and oversights by the person in charge of maintaining individual files. Our population included all admissions from January 1 , 1974, through July 1, 1975, who were terminated before July 31, 1975. Our total of 85 cases included 60 Jnplanned Releases and 25 Planned Releases. A random numbers table was used to draw a $40 \%$ sample from 
each category. Our sample units were made up of 11 Planned Releases and 24 Unplanned Releases.

Since our design ineluded diserete data, we performed a descriptive analysis, noting frequency, mode and mean on demographic characteristics. We compared percentages of Planned and Unplanned Releases on tables of percentage around each variable draw from categories on the data collection sheet. A copy of the data collection sheet is available in the appendix, Section A. 
CHAPTER IV

PRESERTMATION OF DATA

Results

There are three general questions we are examining in our study. Following each question are the results of our findings including tables and comments answering the questions. In this chapter we have focused on documenting our results rather than drawing trends or implications.

A total of eighty five children were included in our study, from which a $40 \%$ random sample was drawn after separating Unplanned Release and Planned Release groups. A single child is vorth $4 \%$ in the Unplanned Release group and $9 \%$ in the Planned Release group.

Iiteral interpretation of our tables should be hedged by recognizing that the differences in percentages between groups may, in some cases, be a result of which children end up in the random sample rather than clear differences between the Unplanned Release and Planned Release groups.

I. Is there a difference between groups based on demographic factors gich as age, race, location of family residence, family's economic status and position in sibline?

A. Age - Unplanned Release Group - Mean age 14.4 years. Planned Release Group - Mean age 15.0 years. The mean age for the Unplanned Release roup is slightly younger. 
B. Race - The child's racial origin was not a distingaishing variable since only two children of other than Caucasian origin were included in the sample frame. The two non-Caucasian children were a half and a full-blooded Indian youth. Both fell under the Unplanned Release group.

c. Location of child's residence in natural or surrogate family before placement.

TABIF I

GEOGRAPHICAL IOCAPION

$45 \%$ or 11 children of the Unplanned group lived in the Metro area.

$55 \%$ or 14 children of the Unplanned group lived outside of the Metro area.

$55 \%$ or 6 children of the Planned group Iived in the Metro area.

$45 \%$ or 5 children of the Planned roup lived outside of the Metro area.

The data above illustrates that $10 \%$ more of the Planned

Release group lived in the Metro area.

D. There was very little difference between the Unplanned and the Planned Release groups with a nearly equal percentage of both falling in the middle class range in the following table. 
PABLE II

FCONOKIC STATUS OF PARHWMS

\begin{tabular}{lcc}
\hline & $\begin{array}{c}\text { Unplanned } \\
\text { Release }\end{array}$ & $\begin{array}{c}\text { Planned } \\
\text { Release }\end{array}$ \\
\hline Welfare & $20 \%-5$ & $18 \%-2$ \\
Middle Class & $76 \%-19$ & $82 \%-9$ \\
Opper Class & $4 \%=\frac{1}{25}$ children total $\frac{-2}{11}$ \\
& total children \\
\hline
\end{tabular}

1. Chronological ordex of children in family.

TABIE III

CHIID'S POSITION IN SIBLINE

\begin{tabular}{cc}
\hline Unplanned Release & Planned Release \\
\hline $12 \%-3$ only children & $9 \%-1$ first child \\
- & $9 \%-1$ second child \\
$32 \%-8$ middle children & $54 \%-6$ middle children \\
$48 \%-12$ last in sibline sibline & $27 \%-3$ last in sibline \\
4.6 average number of \\
children in each \\
family
\end{tabular}

Fifty-four percent more of Planned Group are middle children.

Twenty percent more of the Unplanned group were positioned

last in the sibline. The last and next to last child

positions combine to make up $80 \%$ of Unplanned Group. Many

of the Unplanned Release group are the youngest children in

their family of origin.

II. Does the social history of the Unplanned Release group differ from that of the Planned Release group? 
A. Is there a difference in the number of out-of-home placements prior to admission?

TABIE IV

OUT OF HOME PLACEMENTS PRIOR TO PLACEMIENT

\begin{tabular}{lcc}
\hline & $\begin{array}{c}\text { Enplanned } \\
\text { Release }\end{array}$ & $\begin{array}{c}\text { Planned } \\
\text { Release }\end{array}$ \\
\hline None & $20 \%-5$ & $9 \%-1$ \\
Few (1 or 2) & $64 \%-16$ & $63 \%-7$ \\
Nany (3 ox more) & $16 \%-4$ & $27 \%-3$ \\
\hline
\end{tabular}

Based on the above data there appears to be no difference

between Unplanned Release and Planned Release group.

B. Is there a difference in the number of recorded runaways prior to admission?

TABIE V

RECORDED RUNAWAYS PRIOR TO PLACEMERTP

\begin{tabular}{lrl}
\hline & $\begin{array}{c}\text { Unplanned } \\
\text { Release }\end{array}$ & $\begin{array}{c}\text { Planned } \\
\text { Release }\end{array}$ \\
\hline None & $4 \%-1$ & $18 \%-2$ \\
Few (1 or 2) & $20 \%-5$ & $27 \%-3$ \\
Many (3 or more) & $76 \%-19$ & $55 \%-6$ \\
\hline
\end{tabular}

There appears to be a slightly higher percentage of the

Plamed Release group in the first two categories (None-Few).

Conversely, the Unplanned Release group has $20 \%$ more in the

"many" category ( 3 or more runs). Porhaps this data would

be more useful in predicting Planned Release or Unplanned

Release if we had used defined categories beyond 3 or more rrmaways.

c. Is there a difference in the percentage of children using drags or alcohol prior to admission? 
TABIE VI

CEIID'S AICOHOL OR DRUG USE PBIOR TO PIACEHUFNIP

\begin{tabular}{lccccc}
\hline & \multicolumn{2}{c}{ Unplanned Relesse } & \multicolumn{2}{c}{ Planned Release } \\
\hline & Yes & No & Yos & Io \\
\cline { 2 - 5 } Drug Use & $72 \%-18$ & $28 \%-7$ & $54 \%-6$ & $45 \%-5$ \\
Alcohol Use & $32 \%-8$ & $68 \%-17$ & $36 \%-4$ & $64 \%-7$ \\
\hline
\end{tabular}

This data was extracted from the referral letter or medical intake before a child took up residence at Albertina Kerx Center. The data is limited by what the referring Social Worker chose to include or exclude, and what the child did or did not admit to the nurse at Albertina Kerx Center. Eighteen percent more of the Unplanned Release group were reported to have used drugs than the Planned Release group. There appears to be no difference between the Unplanned Release roup and Planned Release group regarding alcohol use prior to admission.

D. Is there a difference in the number of parents reported to use alcohol by the referring Sooial Worker?

TABIE VII

PAREATIS' USE OF AICOHOL

\begin{tabular}{lcccc}
\hline & \multicolumn{2}{c}{ Unplanned Release } & \multicolumn{2}{c}{ Planned Release } \\
\hline & Yes & No & Yes & No \\
Parents' Alcohol Use & $28 \%-7$ & $72 \%-18$ & $36 \%-464 \%-7$ \\
$\begin{array}{l}\text { Mentioned in the } \\
\text { Beferral Ietter }\end{array}$ & & & & \\
\hline
\end{tabular}

There appears to be very little difference between groups based on parents' alcohol use. 
E. Is there a difference in the number of children having chronic bealth problems prior to admission?

TABLE VIII

GHTIDREAN'S CHRONIC HEALTH PROBLFPSS

\begin{tabular}{lcccc}
\hline & \multicolumn{2}{c}{ Unplanned Release } & \multicolumn{2}{c}{ Planned Release } \\
\hline & Yes & No & Yes & No \\
\hline Psychosomatic Complaints & $32 \%-8$ & $68 \%-17$ & $18 \%-2$ & $82 \%-9$ \\
$\begin{array}{l}\text { Referred Child has a Chronic } \\
\text { Health Problem }\end{array}$ & $32 \%-8$ & $68 \%-17$ & $9 \%-1$ & $91 \%-10$ \\
$\begin{array}{l}\text { Parents of Referred Child has } \\
\text { a Chronic Health Problem }\end{array}$ & $36 \%-9$ & $64 \%-16$ & $18 \%-2$ & $82 \%-9$ \\
\hline
\end{tabular}

The table above reveals a large difference between groups based on reported major health problems. Note that $21 \%$ more of the children in the Unplanned Release group have a chronic health problem. It is also interesting to note that, with one exception, every child who had a chronic health problem came from a family where at least one parent also had a chronic health problem. It appears that children with chronic health problems are more likely to be Unplanned Releases at Albertina Kexr Center.

F. Is there a difference in the number of parents having chronic health problems at the time of their child's admission? Refer to the table used in the previous question. Eighteen percent mose of the Unplanned Release group have parents with reported chronic health problems. 
G. Is there a difference between groups based on natural parents' maxital status?

\author{
MABLE IX
}

NATURAI PARENTPS MARITAI STAPUS

Unplanned Release Planned Release

\begin{tabular}{|c|c|c|}
\hline $\begin{array}{l}\text { Still Married } \\
\text { Divorced } \\
\text { Both Deceased } \\
1 \text { Parent Deceased and } \\
1 \text { Parent Deserted } \\
\text { Widowed }\end{array}$ & $\begin{array}{r}32 \%-8 \\
60 \%-15 \\
4 \%-1 \\
4 \%-1 \\
-\end{array}$ & $\begin{array}{c}27 \%-3 \\
63 \%-7 \\
=\end{array}$ \\
\hline
\end{tabular}

Based on the data above, there is no difference between the Unplanned Release and Planned Release group based on the variable of parents' marital status.

H. Where the family is disrupted by divorce or separation, is there a difference in the length of time since the separation of the natural parents?

TABLE X IFPNGTH OF TIME SEPARATEDD - NATURAI PABEANTS

\begin{tabular}{lcc}
\hline & Unplanned Release & Planned Release \\
\hline 1 to 5 years & $20 \%-5$ & - \\
More than 5 years & $48 \%-12$ & $64 \%-7$ \\
Still Married & $32 \%-8$ & $36 \%-4$ \\
\hline
\end{tabular}

It is notable that $20 \%$ of the natural parents in the Unplanned Release group have been separated less than fire years and all parents. in the Planned Release group have been separated more than five years. 
I. Do the two groups differ in their living arrangements before admission to Albertina Kerr Center?

TABIE XI

6

CHITD'S PLACE OF RESIDEHCE BEFORE PLACEHIEHIT

\begin{tabular}{|c|c|c|}
\hline & $\begin{array}{c}\text { Enplanned } \\
\text { Release }\end{array}$ & $\begin{array}{l}\text { Planned } \\
\text { Release }\end{array}$ \\
\hline $\begin{array}{l}\text { Natural Mother } \\
\text { Natural Father } \\
\text { Both Hatural Parents } \\
\text { Natural Mother and Stepfather }\end{array}$ & $\begin{aligned} 24 \% & -6 \\
4 \% & -1 \\
16 \% & -4 \\
4 \% & -1\end{aligned}$ & $\begin{aligned} 9 \% & -1 \\
\% & -1 \\
- & -\end{aligned}$ \\
\hline$--\infty-\infty-\infty-\infty-\infty$ & $--\infty$ & --- \\
\hline $\begin{array}{l}\text { Foster Parents } \\
\text { Relatives } \\
\text { Institutions } \\
\text { Shelter Care } \\
\text { Friends }\end{array}$ & $\begin{aligned} 8 \% & -2 \\
& -2 \\
36 \% & -9 \\
4 \% & -1 \\
4 \% & -1\end{aligned}$ & $\begin{aligned} 27 \% & -3 \\
9 \% & -1 \\
36 \% & -4 \\
9 \% & -1 \\
& -\end{aligned}$ \\
\hline
\end{tabular}

On this table the data is widespread and not conclusive. It is notable that $48 \%$ of the Enplanned Release group were living with at least one natural parent at the time of placement. A slightly highex percentage of the Planned Release group were residing in foster care. Both groups had an equal percentage frow institations.

J. Do the two groups differ with respect to kind and seriousness of law violations prior to admission?

TABLE XII

STATUTORY OFFENSES PRIOR TO ADMISSION

\begin{tabular}{ccccc}
\hline & \multicolumn{2}{c}{ Unplanned Release } & \multicolumn{2}{c}{ Planned Release } \\
\hline & Yes & No & Yes & No \\
\hline Statutory Offenses & $40 \%-10$ & $60 \%-15$ & $9 \%-1$ & $90 \%-10$ \\
\hline
\end{tabular}


Thirty-one percent more of the Unplanned Release group had been charged with Statutory offenses.

K. Is there a difference in school achievement as measured by appropriate grade placement?

Both groups areraged one grade level below the appropriate level for their age.

I. Does one group include more adopted children than the other? Our sample included only one child who was adopted. This child was the youngest child in a family in the Unplanned Release group.

III. Are there differences between groups in post-admission treatment and behavior?

A. Are there differences in the number of runaways during the first three months after admission?

TABLE XIII

NOMBER OF RUNAWAYS DURING THE FIRST THRRER MONTHS

Unplanned Release Planned Release

$\begin{array}{lrl}\text { Hone } & 4 \%-1 & 54 \%-6 \\ \text { Few (1 ox 2) } & 60 \%=15 & 27 \%=3 \\ \text { Many } & 36 \%-9 & 18 \%-2\end{array}$

Fifty-four percent of the Planned Release group had no runaways within the first three months after placement as compared to $4 \%$ in the Unplanned Release group. Ninety-six percent of the Unplanned Release group had one or more runaways during the first three months as compared to $45 \%$ of the Planned Release group. 
B. Is there a higher incidence of children who end up as Unplanned Release in some living groups?

TABIE XIV

IIVIUG GROUP PLACRUIBNT

\begin{tabular}{|c|c|c|}
\hline & Unplanned Release & Planned Release \\
\hline $\begin{array}{l}\text { Lakin } \\
\text { Jean } \\
\text { Lynn } \\
\text { Sunnyside }\end{array}$ & $\begin{array}{r}24 \%=6 \\
28 \%=7 \\
44 \%=11 \\
4 \%=1\end{array}$ & $\begin{aligned} 45 \% & -5 \\
5 \% & -2 \\
45 \% & -5 \\
& -\end{aligned}$ \\
\hline
\end{tabular}

Based on this data we cannot establish clear differences between living groups, since our percentages may be more a result of which children fell in our sample rather than revealing actual effectiveness of different living groups. C. Is there a difference between groups in the frequency with which parents are involved in treatment?

\section{TABLE XV}

PABERTS INTOLVED IN TREATMUANTI

\begin{tabular}{lcc}
\hline & Unplanned Release & Planned Release \\
\hline Never & $80 \%-20$ & $18 \%-2$ \\
Seldom (1 or 2 times) & $16 \%=4$ & $27 \%-3$ \\
Often (3 or more) & $4 \%-1$ & $54 \%-6$ \\
\hline
\end{tabular}

It is notable that 55\% of the Planned Release group had parents which were involved in treatment three or more times. Increased parental involvement parallels these children's length of time in residence. Because of this parallel finding, it is not clear whether parents were involved because children were in residence longer or if 
children remained longer, using treatment more effectively because parents were involved in solving family problems. Another percentage worth noting is that $80 \%$ of the parents of children in the Unplanned Release group were never inrolved in treatment. Again, it is not clear whether this is a reflection of parental attitude, child's length of stay, or child's place of residence.

D. Are children who have had pre-placement visits more likely to fall in the Planned Release sroup?

TABIE XVI

PRE-PIACFMENT VISIT

\begin{tabular}{ccccc}
\hline & \multicolumn{2}{c}{ Unplanned Release } & \multicolumn{2}{c}{ Planned Release } \\
\hline Yes & No & Yes & No \\
\hline $68 \%-17$ & $32 \%-8$ & $63 \%-7$ & $36 \%-4$ \\
\hline
\end{tabular}

No, children who have had pre-placement visits are not more

Iikely to fall in the Planned Release group.

E. Is there a difference in length of time in residence between the two eroups?

TABLE XVII

LEWTIP OF TIME IN RESIDENCE

\begin{tabular}{lccc}
\hline & & Unplanned Release & Planned Release \\
\hline 0 & -2 months & $56 \%-14$ & - \\
$2.1-4.0$ & $n$ & $24 \%-6$ & - \\
$4.1-6.0$ & $n$ & $4 \%-1$ & $18 \%-2$ \\
$6.1-9.0$ & $n$ & $8 \%-2$ & $27 \%-3$ \\
$9.1-12.0$ & $n$ & $8 \%-2$ & $18 \%-2$ \\
$12.1-15.0$ & $n$ & - & $18 \%-2$ \\
$15.1-19.0$ & $n$ & -2 & \\
\hline
\end{tabular}


Although the range is widespread, there are obvious differences between groups. For example, $56 \%$ of the Unplanned Release group were in residence less than two months; whereas all of the Planned Release group were in residence at least 4 months. Twenty percent of the Unplanned Release group were in residence 4 to 15 months as compared to a hundred percent of the Planned Release group who were in residence 4 to 19 months. 


\section{CHAPTER V}

\section{CONCLUSIONS}

\section{Implications}

It is apparent from our data that Albertina Kerm Center residents, during the period under study, included a severe runaway population. In our sample, only one of the Unplanned Release group had no recorded elopements prior to placement, and only one did not run during the first 3 months. In the Planned Release group, only two had no runs prior to placement, though a larger number, 6, did not run during their first three months in residence. In general, the Planned Release group ran less often both before and after placement; so for purposes of discussion we are designating this the low-runner group, while the Unplanned Releases are equated with the habitual or chronic manners in other studies: This distinction, while not precise, is useful in comparing our results to the findings of other authors.

Many of our results tend to support those of Colbeth et al. $47(1975)$ whose study is particularly relevant because Albertina Kerr residents were included in the population studied. Their research compares a group of 25 youngsters who ran away from six institutions daring a one month period, with a matched group of 25 who did not run. They designated the former group "runners" and the lattex "non-runners", though in fact most of the non-runner group ran away at other times. 
In their overell sample Colbath et al. found no difference in the mean age of runners and non-runners, a finding similar to ours; though in our sample the low-runner group tended to be slightly younger. It does appear from the data available so far that age is not a factor differentiating habitual runners from low-runners.

Colbath et al. also contrasted the racial composition of their groups, finding that both were primarily Caucasian. Our total sample contained only two non-Caucasians, a ratio which is roughiy equivalent to that of the entire Albertina Kerr Center population at any given time. The reason appears to be that minority group children are seldom referred for treatment. Albertina Kerr Center does not discriminate on the basis of race and the staff is aware that they are seldom asked to consider a non-Caucasian applicant. An interesting side question, too complex to deal with here, is why so few minority group children are referred. With respect to location of the child's residence, Colbath et al. found a significant difference between groups: Subjects were more Iikely to run if they lived outside the Portland Metropolitan area, where all the institutions being studied were located. Our results show a similar trend, though not as pronounced: We note that they may have been more significant had we chosen to linit the definition of the metropolitan area to a smaller territory. Our definition included one fair sized town, Hillsboro, approximately 40 miles from Portland. It is worth noting that the Hale study, done at the Utah State Industrial School, and the Levine Study at the Illinols State Praining School, reported findings similar to ours and Colbath's. The consistency of such results suggests that the distance of a child's home from the institution is a factor worth considering in deciding on placement. 
Regarding economic status of a child's family, we found, Iike Ninnes ${ }^{48}$ (1966), no difference between groups. Our categories were so loosely defined that the results are not particularly informative, except for the interesting fact that the population of Albertina Kerr Center tends to be quite homogeneous in that less than one fifth of the girls have parents on Welfare. The agency appears to be serving the children of midjdle class families, according to our loose definition used in this study.

While our results showed virtually no difference in size of family between groups, there was a marked trend for habitual runners to be the youngest or next to youngest in the family of origin, while the lowrunners were more frequently middle children. This finding contrasts with Greer et al. ${ }^{49}(1972)$, who found runaways were apt to be the oldest. Since the Greer study did not focus on institutionalized children, we speculate that oldest children may be more skilled at survival when they do run, a hunch which is supported by the fact that only one of our total sample is a first child. This child was in the low-run group. There were 3 only-children in the habitual-runner group, but we categorized them separately because their relationship to family as a whole differs from that of the oldest.

In considering the number of out-of-home placements girls experienced before admission to Albertina Kerr Center, we were surprised to find that the Unplamned Release group had a slightly larger percentage of gixls with no previous placements than the Planned Release group. However, the difference was slight; in general the majority of the girls had 1-2 prior placements, a result very similar to Colbath's et al., who report the mean number of prior placements for Runners as 1.57, while 
the mean for Non-Runners was $2.14 .^{50}$

In considering recorded elopements prior to placement, there is a decided trend toward more frequent runs in the Unplanned Release or habitual-runner group. These results support the simple proposition that a child who has developed muning behavior as a means of coping is apt to retain this coping device when placed in an institution. Our results in this category may have been more meaningful had we broken down the "Many" category into smaller units. As it is, this category includes all subjects who ran 3 or more times prior to placement, hence fails to distinguish between the girl who ran 3 times and the girl who $\operatorname{ran} 20$.

Both Levine ${ }^{51}(1962)$ and Huling ${ }^{52}(1966)$ study the incidence of drug and alcohol use in munaway and non-runaway groups in institutions. Huling found no significant difference between groups, but Levine reported that children referred because of substance abuse were 4 times as likely to mun as those referred for other offenses. Our results with respect to drug use tend to support Levine's findings, but those pertaining to alcohol use are the reverse: $i . e .$, slightly more of the lowrunaway group used alcohol prior to admission. We speculate that girls with more serions relationship problems tend to use drugs, or perhaps drug use results in more serious relationship problems than the use of alcohol. It seems important to stress here that our results are likely to have been more descriptive if we had distingrished between occasional and regular users, and, in the case of drugs, between marijuana and hard drugs.

Interestingly, there does not appear to be any particular relationship between alcoholic parents and a girl's use of alcohol, while 
percentages of alchol use are almost identical, the girls who drank did not come from alcoholic families.

In the area of health problems, there is a definite correlation between parent and child: In instances where a girl had a chronic health problem she was apt to have a parent who was similarly afflicted. While the girl's health difficulties were real in the sense that they had a physical basis, they were most frequently of a type which might be associated with emotional disturbance; for example the most common were upper respiratory infections. One implication of this finding is that the girls who had chronic health problems had learned, in their families of origin, to translate emotional distress into physical symptoms as a means of avoiding anxiety. It is notable that there is a higher incidence of chronic health problems in the chronic ranaway sroup, and that this group also evidenced more symptoms identified as psychosomatic.

In comparing our two groups with respect to parents' marital status, we found, Iike Colbath et al., very Iittle difference. However, the overall high degree of family dismuption substantiates the view that munaway-delinquent behavior is related to family disturbances, as reported by the bulk of the literature.

It. seems worth noting thet, in $20 \%$ of the chronic runaway group, parental separation occurred within 1-5 years of placement, while in all instances the low-runaway group had parents who had been separated more than five Jears. We speculate that in those cases where the reparation had occurred more recently, the girl may have had more unregolved feelings about the family disruption, hence a higher degree of anxiety about placement. 
In this connection it is interesting to note that $48 \%$ of the habitual runners were living with one or both natural parents prior to placement, while only $18 \%$ of the low-munawas group had such living arrangements. The implication we see here is that it is apt to be more difficult for a girl to adjust to the Albertina Kerr Center when she is placed from her own home than when she is Iiving in a foster home or an institution prior to placement.

Another trend we found in the chronic runaway group which was not present in the low-mun group was a larger number of statutory offenses: 10 of the girls in the former group had comitted such offenses, while only one of the girls in the latter group had done so. These figures suggest that the girl who has committed a serious offense is less likely to be amenable to treatment at Albertina Kerr Center than the girl whose delinquency involves jurenile code violations only.

Our data concerning school performance was very limited due to unavailability of information, but it is apparent that the Albertina Kexr Center popalation as a whole has more difficulty in school than the general population, since the total the children in the sample are behind in school an average of 1 year, even considering the maximam age at which a child might normally be in a given grade. This finding concurs with the Greer study, in which runaways in general are described as having more trouble in school than the normal population. While the possible causes of these difficulties are too numerous and complex to consider here, such findings clearly support the concept that the school program is a vitally important aspect of treatment.

Our data regarding the pre-placement visit tends to confirm the findings of Colbath et al., that a girl's running record after placement 
was not a function of whether or not she had a pre-placement visit. We do not conclude from these results that a pre-placement visit is not important, because there is no data to indicate what experiences were offered the girl on her visit. This is an area that seems worth further research.

One of the most significant findings in owr study is that, with one exception, the habitual zunner eloped at least once in the first 3 months of placement, while 55\% of the low-ron group did not run during this period. Of equal significance is the fact that the majority of Unplanned Releases remained in residence less than two months, a finding reported again and again in the literature. Hence it is apparent that the first two months are critical, suggesting that special attention needs to be given to helping a girl adjust to her new environment. Ievine, who noted that a high percentage of runs occurred in the first 30 days after a student was placed in the Illinois State Training School, hypothesized that such behavior was due to separation anxiety. We note that some of the findings in our study tend to support this hypothesis as a possible explanation for the behavior of part of our Unplanned Release group. Specifically the finding that $48 \%$ of the Unplanned Releases were living with one or both natural parents at the time of placement may be assumed to jndace a higher degree of separation anxiety than that experienced by a child who has already undergone separation from both natural parents. The higher frequency of more recent family disxuption in the Jnplanned Release group hints at increased anxiety at placement in the gixls who have had such an experience. The fact that the youngest child in the siblings tends to be a runner may also relate to the hypothesis; since, as youngest children, they may have more 
infantile ties to the family.

As an addendum to our study we compiled a table illustrating each girl's delinquent behavior, to deternine whether the girls in the Unplanned Release group were involved in more kinds of delinquency than those in the Planned Release group. (See Appendix, Section B, for table) While the deta does not appear to reflect a decided difference between the two groups, we note that 9 (36\%) of the Unplanned Releases had been involved in 3 or more kinds of delinquent behavior prior to admission, while only $2(18 \%)$ of the Planned Releases had an equal degree of delinquency. In the Unplanned Release group one resident had a record of delinquent behavior in all four categories; while none of the Planned Releases were delinquent to this degree. The data suggests that girls who have been seriously involved in more than two of the four categories of delinquency are poor treatment risks at Albertina Kerr Center. Again, had we made more distinction within categories, our results are likely to have been more meaningful.

\section{Recomendations}

Our study suggests that there are two general categories of chronic runaways at Albertina Kerr Center. The first is the character disordered child whose history may include three or more of the following delinquent behariors: 1. Numerous runs preceding admission; 2. Drag use; 3. Alcohol use; 4. One or more statutory offenses. We believe these girls need a looked facility if they are to be treated, and recomend that Albertina Kerr Center either develop greater security measures or refer such applicants to another facility.

The second kind of chronic ranaway appears to be the child who is experiencing separation anxiety. She is apt to be placed from her own 
home, to have more infantile family ties, and perhaps to have undergone a recent family disraption. On the assumption that there is validity to this hypothesis, we recomend developing ways of helping new girls deal with separation, by providing opportwaities to express their feelings about being away from home. The girl who is suffering from separation anxiety needs to be helped to deal with her painful feelings, rather than encouraged to distract herself from them; both the one-to-one counselling and small groups now avallable at Albertina Kerr Center might be used in this way.

Our second recommendation for the new girl is a structured orientation program designed to lessen her anxiety about the strange setting. Such a program might include a pre-placement visit at which a staff member takes time to get to know the girl and answer her questions. Upon admission, the same adult would ideally be available to her to acquaint her with her surroundings and familiarize her with the structure of the program. The desigmated adult would then remain the primary staff person to whom the girl could turn with problems arising during her residence. Consideration might also be given to appointing a "Big Sister" for each new girl. Many programs have found it helpful to appoint a girl who has been in residence long enough to be well adjusted, to serve in this capacity. The Big Sister provides support, introduces the new arrival to the other girls, and generally watches out for her.

our final recommendation addresses the problem of premature termination by agencies other than Albertina Kerr Center. We suggest that Albertina Kerr Center establish a policy explicitly stating the requirement that girls be returned from runs until the Albertina Kerr Center and the referring agency make a mutual decision to terminate treatment. 
A contract sigmed prior to placement by all concermed parties, including parents, might be helpful. Consideration might also be given to negotiating a general contract with Children's Services Division, in which agreement to this policy is a condition of admission. The expectatfon that a girl will be returned following roms might be included in referral material sent to agencies and parents.

We realize such a policy would create mechanical problems for Albertina Kexr Center, but believe they would be outweighed by the advantages of increased continuity of care and more consistent planning for the girls.

\section{Areas for Further Research}

One important area which our study did not cover was that of interactions within the facility which may stimulate runs, such as conflict between staff and girls, or between a girl and her peers. Another provocative area is that of the relationship between parental attitudes and the girls' adjustment to the treatment program. At this point in our reseerch it is impossible to estimate how great a part these influn ences may play in determining whether or not a girl runs away, though we speculate they are likely to be crucial in some cases.

Two specific areas of research are suggested to follow np on this study. The first consists of designing and assessing the effectiveness of an orientation program for new girls, perhaps using a control group with whom the new orientation procedures are not used. Second, a study might be designed to exploxe, in depth, those delinquent behaviors which appear to suggest that a girl is an inappropriate candidate for treatment in an unlocked facility. 
Nomerous other possibilities are suggested by the existing literatwre, and by the trenda noted in this study. Certainly the difficult and complex problem of runaway youth offers many challenges to social research. 
FOOTNOTES

${ }^{1}$ Vedder, Clyde B., Juvenile Offenders, Springfield, IIl.: Charles Thomas, 1963. p. 189.

2 Ioid., p. 195.

3oid., p. 198-199.

${ }^{4}$ Ioid., p. 208.

${ }^{5}$ Slater, Eliot; Cowie, John; and Cowie, Valeria; Delinguency in Girls, London: Heinemann Education Books Ltd., 1968.

${ }^{6}$ Ioid., p. 182 .

${ }^{7}$ Cavan, Ruth Shonle, Juvenile Delinquency, New York:

J. B. Iippincott Company, 1962.

$$
\begin{aligned}
& { }^{8} \text { Ibid., p. } 64 . \\
& { }^{9} \text { Ibid., p. } 125 . \\
& { }^{10} \text { Ibid., p. } 109 .
\end{aligned}
$$

11 Arieti, Silvano Ed., American Handbook of Psychiatry, Vol. 3, "The Therapeutic Community" by Alan M. Kraft, pp. 542-552, New York/Lonäon: Basic Books, Inc., 1966, p. 543.

12 Ibid., p. 545.

13 Whittaker, James K. and Trieschman, Albert E., Eds., Children Away From Home, Chicago and New York: Aldine-Atherston, 1972. "The Concept of a Therapentic Milieu," Redl, Fritz, pp. 55-69.

14racorkle, Lloyd; Elias, Albert; and Bixby, F. Lovell; the Eighfields Story, New York, Henry Holt, 1958.

${ }^{15}$ Cavan, Ruth Shonle, Op. Cit., p. 338.

16 This statement appears throughout the literature, but its origin is unknown. 
17 Hildebrand, James A., "Why Runaways Leave Home," Jourmal of Criminal Law, Criminology and Police Science, IIV, June, 1963, 211-216.

18 Nye, Ivan F. and Short, James F., "Scaling Delinquent Behavior," American Sooiological Review, XXII, June, 1957, pp. 326-331.

${ }^{19}$ Shellow, Robert; Schamp, Juliana; Liebow, Elliot; and Unger, Flizabeth; "Suburban Runaways of the $1960^{\prime} \mathrm{s}$," Monographs of the Society for Research in Child Development, XXXII, No. 3, 1967, pp. 1-37.

20 Ambrosino, Iillian, Runawars, Boston, Beacon Press, 1971, p. 31.

${ }^{21}$ Greer, Susan G.; Hertlein, Sarah J.; and Regner, Stephen C.; A Study of the Characteristics of Runaways and Their Families in Two Social Agencies," Unpublished Mastex's Practicum, Portland State University School of Social Work, 1972, p. 109.

22 Thom, D. A., Normal Youth and Its Bveruday Problems, New York, Appleton, 1933.

23 Ibid., p. 245.

24 Robey, Amos and Rosenwald, Q. E., "The Runawry Girls; a Reaction to Family Stress," American Joumal of Orthopsychiatry, Vol. 34, No. 4, 1964.

25 Wylle, Dorothy C. and Weinreb, J.; nThe Treatment of a Runaway Adolescent Girl Through the Treatment of the Mother," American Journal of Oxthopsychiatry, XXVIII, January, 1958.

26 Foster, Randall M., "Intrapsychis and Environmental Factors in Rumning Away from Home," American Joumal of Oxthopsychiatry, XXXIV, April, 1962, pp. 486-491.

27 Ibid., p. 491.

28 Blood, Iinda and D'Angelo, Rocco, "A Progxess Research Report on Value Issues in Conflict Between Runaways and Their Parents," Journal of Marriage and the Family, Vol. 36, No.3, August, 1974; PP. 486-491.

${ }^{29}$ Ibid., p. 490.

30 Reimer, Morris D., "Runaway Children," American Joumal of Oxthopsychiatry, Vol. X, July, 1940; pp. 522-526.

31 Balser, B. H., "Behavior Problem-Runaways," Psychiatric Quarterly, XIII, 1939, pp. 539-557.

${ }^{32}$ Greer, et al., Op. Cit.

33 Ibid., p. 2. 
34 Ibid., p. 110.

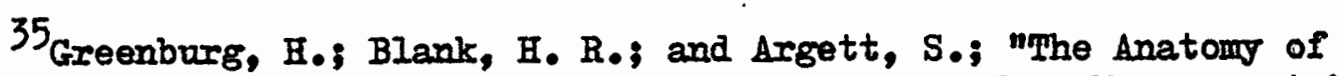
Blopement From an Acute Adolescent Service: Escape From Management," Psychiatric Quarterly, 42: 28-49, 1968.

36 Hale, Ballard John; Ninnes, Brent Wright; and Huling, Clinton H.; "Jtah State Industrial School Runaways," Unpublished Master's Thesis, Graduate School of Social Work, University of Jtah, 1966, Parts 1-3.

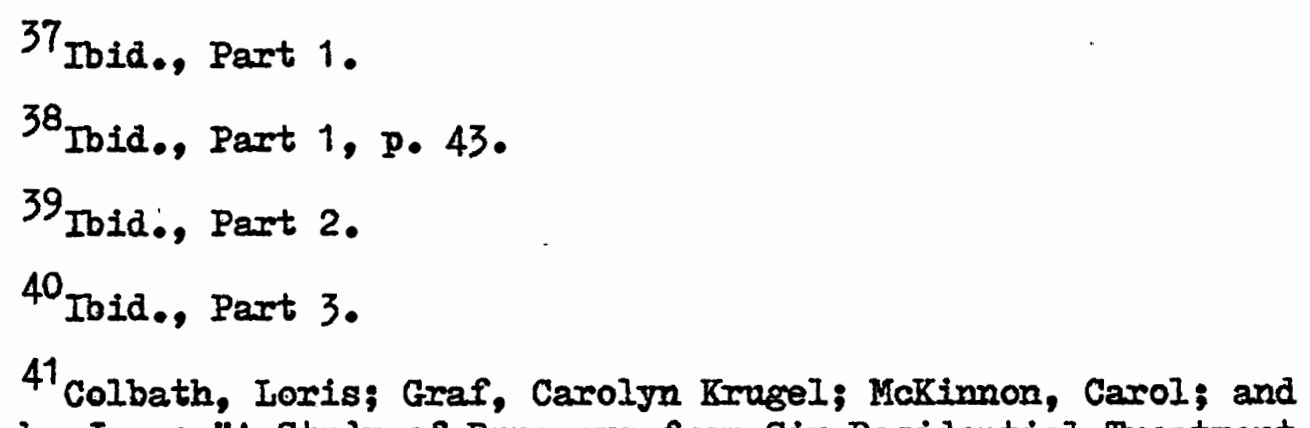
Newcomb, Jean; "A Study of Runaways from Six. Residential Treatment Agencies," Unpublished Master's Practicum, Portland State University School of Social Work, 1975, pp. 1-84.

42 Levine, Stanley; "Runaways and Research in the Training School," Crime and Delinquency, VIII, January, 1962, p. 43.

${ }^{43}$ Cambarexi, John D.; Sagers, Paul S.; and Tatton, Donald; "The A.W.0.L. From a Juvenile Institution," Cxime and Delinquency, 6, July, 1960 ; pp. 275-78.

44 Levy, Edwin Z., "Some Thoughts About Patients Who Run Away From Residential Treatment and the Staff They Leave Behind," Psychiatric Quarterly, Vol. 46 (I), 1972, pp. 1-21.

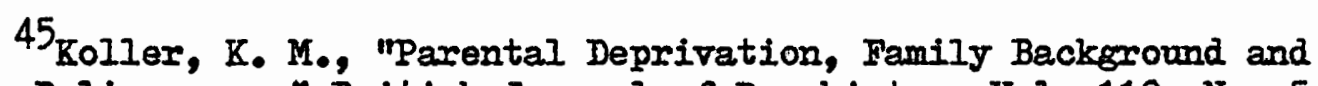
Penale Delinquency," British Journal of Psychiatxy, Vol. 118, No. 544, 1971.

46 Ioid., p. 320.

47 colbath et al., Op. Cit.

$48_{\text {Hale et al., Op. Cit., Part } 1 .}$

${ }^{49}$ Greer et al., Op. Cit.

${ }^{50}$ Colbath et al., op. Cit., p. 50.

${ }^{51}$ Levine, Op. Cit.

52 Hale et al., Op. Cit., Part 3. 


\section{Bibliography}

Ambrosino, Iillian. Runaways. Boston: Beacon Press, 1971.

Arieti, Silvano Ed. American Handbook of Psychiatry, V01. 3

"The Therapeutic Community," by Alan M. Kraft, 542-552.

Hew Yoxk/London: Basic Books, Inc. (1966)

Balser, B. H. "Behavior Problem-Runaways." Psychiatric Qnarterly, XIII (1939), 539-557.

Blood, Iinda and D'Angelo, Rocco. "A Progress Research Report on Value Issues in Conflict Between Runaways and their Parents." Journal of Marriage and the Family, Vol. 36, Ho. 3 (Angust, 1974).

Cambareri, John D., Sagers, Paul S, and Tatton, Donald, "Phe A.W.O.I. From a Juvenile Institution," Crime and Delinquency, Yol. 6, (July, 1960), 275-78.

Cavan, Ruth Shonle, Jurenile Delinquency. New York: J.B. Lippincott Company, 1962 .

Colbath, Loris; Graf, Carolyn Krugel; McKinnon, Carol; and Newcomb, Jean. "A Study of Runaways From Six Residential Treatment Agencies." Unpublished Master's Practicum, Portland State University School of Social Work (1975) 1-84.

Foster, Randall M. "Intrapsychic and Environmental Factors in Running Away from Home." American Journal of Oxthopsychiatry, XXXIV (April, 1962) 486-491.

Greenburg, H.; Blank, H. R.; Argett, S. "The Anatomy of Elopement From an Acute Adolescent Service: Escape From Management." Psychiatric Quarterly, Vol. 42, (1968), 28-49.

Greer, Susan G.; Hertlein, Sarah J.; and Regner, Stephen C. "A Study of the Characteristics of Runaways and Their Families in Two Social Agencies." Unpublished Master's Practicum, Portland State University School of Social Work (1972) 1-140.

Hale, Ballard John; Ninnes, Brent Wright; and Holing, Clinton H. "Utah State Industrial School Runaways," Unpublished Master's Thesis, Graduate School of Social Work, University of Utah (1966) Parts 1-3. 
Haupt, Donald $N_{0} ;$ and Offerd, David B. "Runawrys from a Residential Treatment Center: A Preliminary Report." Comrective Psychiatry and Journal of Social Therapy XVIII (1972) (3)

Hildebrand, James A. "Why Runaways Leave Home." Jowmal of Criminal Iaw, Criminology and Police Seience, IIV (June, 1963) 211-216.

Koller, K. M. "Parental Deprivation, Family Background and Female Delinquency." British Joumal of Psychiatxy Vol. 118, No. 544 $(1971)$.

Ieventhal, Theodore. "Control Problems in Runaway Children." Archires of General Psychiatry, IX (Augast, 1963). 122-126.

Leventhal, Theodore. "Inner Control Deficiencies in Runaway Children." Archives of General Psychiatry, IX (August, 1964).

Levine, Stanley. "Runaways and Research in the Training School," Crime and Delinquency; VIII (Januaxy, 1962), 43.

Levy, Edwin Z. "Some Thoughts About Patients who Run Away From Residential Mreatment and the Staff They Leave Behind." Psychiatric Quarterly, Vol. 46 (I) (1972) 1-21.

MoCorkle, IIloyd; Elias, Albert; and Bixby, F. Lovell. The Highfields Story. New York: Henry Holt, 1958.

Hje, Iran F.; and Short, James F. "Scaling Delinquent Behavior." American Sociological Review, XXII (June, 1957) 326-331.

Reimer, Morris D. "Runaway Children," American Joumal of Orthopsychiatry, Vol. X (July, 1940) 522-526.

Robey, Amos and Rosenwald, Q. R. MTho Runaway Girls; A Reaction to Family Stress." American Joumal of Orthopsychiatry, Vol. 34, No. 4 (1964).

Shellow, Robert; Schamp, Juliana; Iiebow, Elliot; and Unger, Elizabeth, "Suburban Runaways of the 1960 's." Monographs of the Society for Research in Child Development, XXXI, No. 3 (1967) 1-37.

Slater, Bliot; Cowie, John; and Cowie, Valeria; Delinquency in Girls, London: Heinemann Bducational Books Itd., 1968.

Thom, D. A. Normal Youth and Its Everrday Problems, New York: Appleton, 1933.

Vedder, Clyde B. Juvenile Offenders, Springfield, Illinois: Charles Thomas, 1963.

Whittaker, James K. and Trieschman, Albert E. Eds. Children Away From Home, Chicago and New York: Aldine-Atherston, 1972. "The Concept of a Therapeutic Milien," Fritz Redl. 55-69. 
Wylie, Dorothy C., and Weinreb, J. "The Treatment of a Runaway Adolescent Girl Through the Preatment of the Kother", American Joumal of Orthopsychiatry, XXVIII (January, 1958). 
SHDIUNEd dV

। 
APPEIIDIX A

DATA COLTECIION SHEWT

Name

Category (check one)

I. Planned Release

II. Unplanned Release

I. Demographic Data

Age at admission__ No. of children _ _ Position in

\begin{tabular}{|l|l|l|l|l|l|}
\hline \multicolumn{3}{|c|}{ White } & Black & Oriental Indian Mixed \\
\hline Race & & & & & \\
\hline
\end{tabular}

Metro In Oregon Out of State

Area

Out of Metro

\begin{tabular}{l|c|c|c|}
\hline $\begin{array}{l}\text { Location of } \\
\text { Family Home }\end{array}$ & & \\
\hline & Welfare & $\begin{array}{c}\text { Middle } \\
\text { Class }\end{array}$ & $\begin{array}{c}\text { Jpper } \\
\text { Class }\end{array}$ \\
\hline Family's Economic Status & & \\
\hline
\end{tabular}

II. Social Data

A. Out of home placements prior to Albertina Kerr Center

B. Recorded Immawajs prior to placement
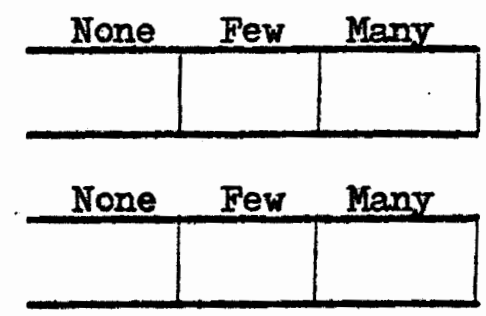

c. Irag ase prior to placement, mentioned in referral letter

C1. Alcohol use, mentioned in referral letter (child)

D. Alcohol use, mentioned in referral letter (parent)

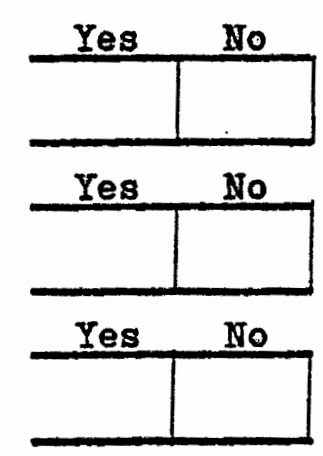


T. Chronic health problem (child)

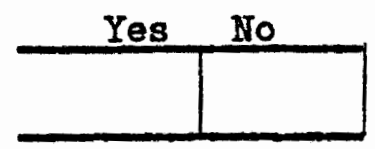

F. Chronic health problem (parent)

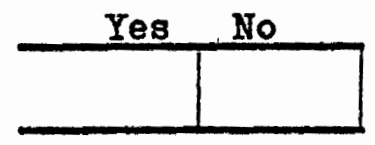

G. Parents' marital status

H. Length of time separated or divorced

Still mamied

Separated

Divorced

Widowed

Never Maxnied

Don't know

Less than 1 re.

1 to 5 yes.

More than 5 yrs.

Not applicable

Don't know

I. Who subject was living with before placement at Albertina Kerr Center:

1. Natural mother

2. Natural father

3. Both 1 and 2

4. Stepmother

5. Stepfather

6. Both 4 and 5

7. Natural mother and stepfather

8. Natural father and stepmother

9. Foster parents

10. Relatives

11. Institution

12. Other

J. Statutory Offense

\begin{tabular}{l|l|} 
Yes No \\
\hline
\end{tabular}

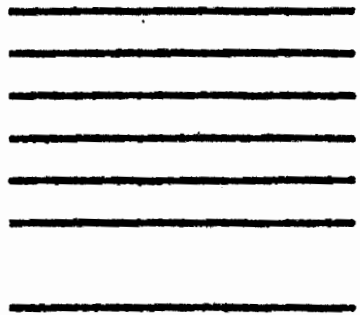

K. Grade in school at time of admission

I. Adopted

\begin{tabular}{l} 
Yes 10 \\
\hline 1
\end{tabular}


III. Institutional Data

A. Number of runaways during first three months after admission

\begin{tabular}{l|l|l|} 
None & Few & Many \\
\hline
\end{tabular}

Lakin Jean Iynn Sunnyside/Elda

B. Living group placement

C. Parents (natural or foster) involved in treatment

\begin{tabular}{|l|l|l|} 
Hever Selaom Often \\
\hline
\end{tabular}

D. Pre-placement Visit

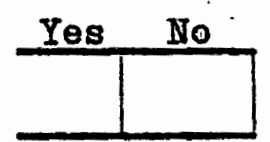

E. Iength of time in residence before release

\begin{tabular}{|l|l|l|l|}
\hline $0-2$ mo. $2: 1-4.0$ mo. $4.1-6.0$ mo. $6.1-2.0$ mo. $9.1-12.0$ mo. \\
\hline & & & \\
\hline
\end{tabular}

12.1-15.0 mo.15.1-19.0 mo.19.1 \& over 
APPENDIX B

COMPARISON OF DELINQUEHT BHRAVIOR

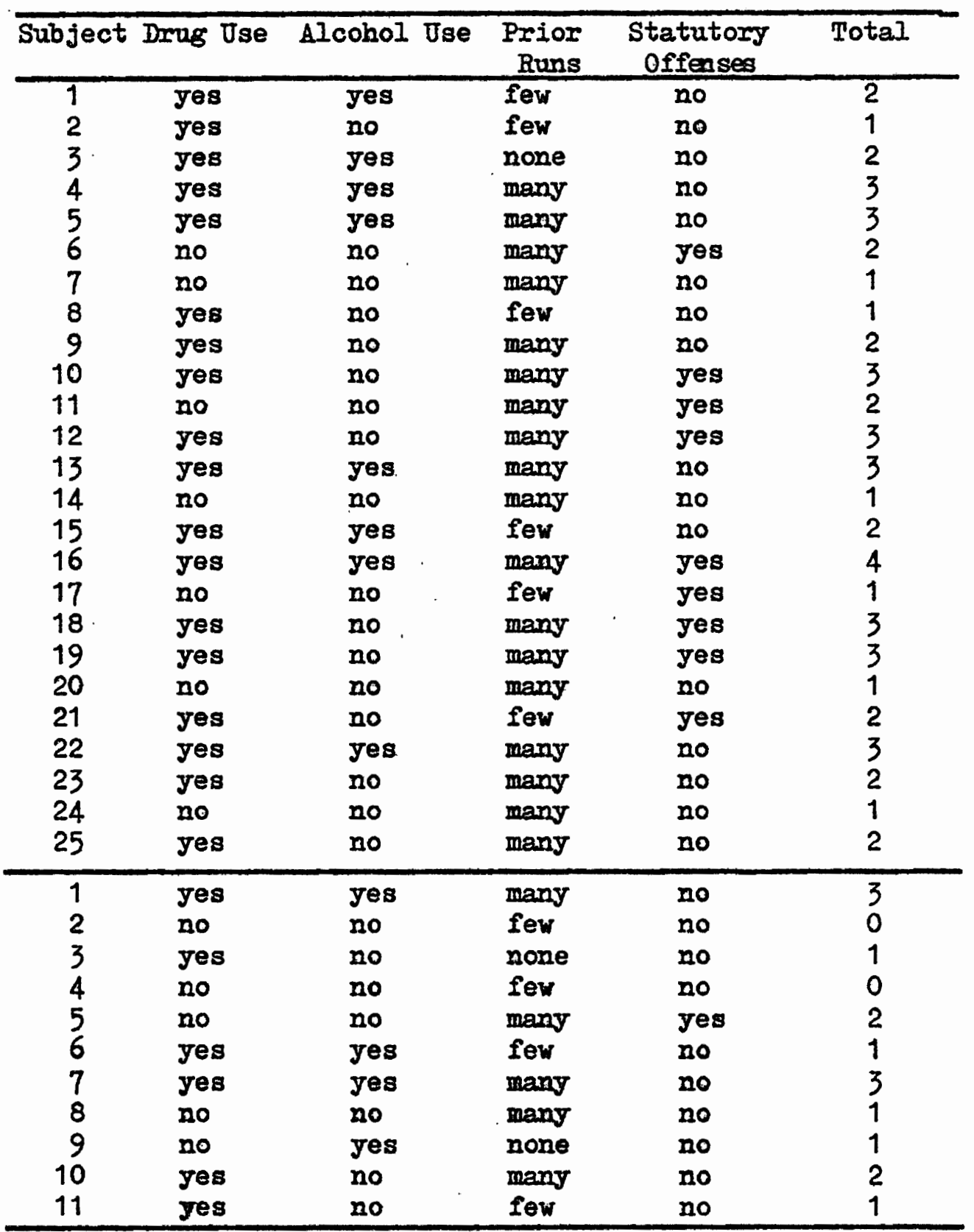

